\title{
Update on Middle East respiratory syndrome corona virus epidemiology, diagnosis and management
}

\author{
Al-Ghamdi $\mathbf{S}^{1}$ \\ ${ }^{1}$ Sameer Al-Ghamdi1, Department of Family Medicine, College of Medicine, Prince Sattam bin Abdulaziz University, \\ Al-Kharj, Saudi Arabia.
}

Address of Correspondence: Sameer Al-Ghamdi, Email: $\underline{\text { sam3443@ gmail.com }}$

\begin{abstract}
In the mid of 2012, Middle East respiratory syndrome otherwise termed as, corona virus (MERS-CoV) emerged among the leading serious infection within the peninsula region with chances of transmission to the most parts of the world. The greatest infection was first confirmed in the Northern part of Saudi Arabia where 50 deaths were experienced and 80 ceases of illness were reported. Apart from the reported cases, possible laboratory reports confirmed that such a compulsory sequence of infection is mainly transmitted through Carmel and bats. While there is no specific cure for corona virus (MERS-CoV), International health governing authorities such as world health organization and the Pan American Health organization (PAHO) have placed recommendations to healthcare institutions of different countries to provide relevant information with regard to preventive measures of the disease. Such has been brought amid skepticism that the disease has no cure. Therefore, regulating prevalence rate of MERS-CoV through means such; as environmental engineering controls, administrative measures and immediate isolation of the infected patients, plays best to curb the rate of infection.
\end{abstract}

Key words: Middle East Respiratory Syndrome, Corona virus, MERS-CoV, Epidemiology.

\section{Introduction}

CDC world health organizations WHO together with other healthcare bodies falling under the European Union and united Arabs emirates believe that countries who are partisans to the treaty should be furnished with adequate information about Middle East respiratory syndrome (MERS) [1]. In light with the presence of such a disease in the peninsular region, all governments of the member countries have been asked to ensure that they avail to healthcare practitioners with relevant information about the infection such as the procedure for handling an infected patient, travel history or any other previous treatment information [2]. Despite the fact that epidemiology of (MERS) seems disastrous to these countries, the CDC and world health organization's do not advise on screening of passengers along the border points or to impose a travel ban among some of the countries deemed to be associated with the infection [3]. Therefore, this paper looks into the

Manuscript received: $12^{\text {th }}$ Dec 2015

Reviewed: $23^{\text {rd }}$ Dec 2015

Author Corrected: $06^{\text {th }}$ Jan 2016
Accepted for Publication: $17^{\text {th }}$ Jan 2016 relevant information about the Middle East Respiratory Syndrome Corona virus Epidemiology, Diagnosis and Management.

The paper studies about the need for testing and what is being done to furnish the concerned parties with enough information about the latest trend of MERS [4].

While other scholars have made a publication of similar kind in the past, it is still found necessary to continually do the same because the level of infection caused by the virus has always been in the rise due to human-animal interaction in the region [5]. Therefore, possible recommendation with regard to consistent update is quite necessary since it gives a leeway to diagnostic and preventive measures [6,7]. First, the latest information about the MERS was brought into public by the WHO in late December 2013 as a confirmation of the infection as a pandemic in the Middle East [8]. In addition, the laboratory report published by the Pan American Health Organizations also pointed out that the escalation of infection is enhanced by movement 
among countries within the United Arabs Emirates (UAE).

Some of such countries include Dubai, Oman, Qatar, Kuwait and lately Lebanon and Iran [10]. However, there is no specific country that has been identified in the report to have topped highest with the level of infection since the residences of such countries often interact to each other on different platforms [11]. To a smaller level, the presence of the diseases was felt in the United States in early 2014 when two of the US journalists from Saudi Arabia showed the symptom of the MERS virus [12]. On the contrary, no further cases of the same have been reported yet in the United States thereafter [13, 14]. Secondly, despite the level of surveillance that has been implemented in some of such countries, majority as many as 500 people have still reported positive of the virus in over 40 countries [15, 16]. From a report by the WHO, it has been observed that the level of infection was much higher between mid-2013 and late 2014 [17]. Moreover, much more information about the disease was received up early 2015 within Saudi Arabia [18]. With reference to cases confirmed in 2015 alone, [19] it can be pointed out that the presence of the infection is still very imminent in the Middle Eastern region and a lot of measures are still needed to curb its escalation [20].

\section{Observation Objective of MERS-CoV infection:} With the availability of an opportunity to achieve a mitigating effort of MERS-CoV infection [21], all health representatives in different countries should develop commitment to control the prevalence rate [22, 23]. The following are some of the mitigating effort that has been employed to control the prevalence of the disease:

1. Employment of early detection mechanism of the virus within the region within peninsular countries [24].

2. Closer monitoring of the infected persons and the geographical region to deter increases of prevalence [25].

3. Determine and implement new preventive measures to prevent the epidemiology, the development cycle and the morbidity of an affected region [26].

4. The relevant healthcare authorities should be furnished with relevant and timely information so that they can similarly do the same to the society $[27,28]$.

Suspension/ shadowing of the MERS virus: As part of a future mitigation effort against the disease, the WHO organization launched a forum in January 2015 in Riyadh to discuss possible measures that can be incorporated to prevent continued prevalence of MERS infection in the Middle East [29]. Part of the information that was discussed during the forum and the report compiled was to be used as part of the recommendation to review $\mathrm{c}$ the extent of prevalence [30,31]. Moreover, laboratory reports from different countries were presented during the discussion and recommendations concerning the results were given [32]. As a matter of concerns, reports that had been discussed in a previous meeting held in France were revised to ascertain possible relationship between the MERS and human relationship [33, 34].

It was discovered that MERS is closely related to a Carmel diseases and there is more likeliness that it is promoted the trade in camel products that is mostly common in the region [35-39]. Therefore, there is a need to establish a temporary institution to gather more information concerning the prevalence of MERS [40].

The CDC together with the world health organization recommends that laboratory centers to engage in tests be put in place. Such centers will be empowered to investigate about camels products and recommend on the relevance between the products and the MERS infection [41]. Moreover, the WHO organizations advised that partisan countries to improve their surveillance and institute a preventive measure to dealing with the chances of emergency occurrence [42]. As a consequent, health practitioners should be exposed on symptoms of the diseases as this would give them easy time to investigate about the patients travel history and the suspected infection as pointed out in Bioinformatics and Functional Genomics (p56-74) [43].

The Criteria for Investigation: Pointing from the previous results and what has been discussed by other scholars about the disease, epidemiological investigation and laboratory testing are recommended. However, the following are some of the possible criteria of what should be incorporated through the process of investigation [44].

If a person shows signs of severity for respiratory syndrome lasting more than 2 weeks or if the patient may have had a previous contact with a patient of MERS victim then he requires tests. While developing such symptoms is not an automatic indication of an infection; it would help in reducing the sample size of those whom should be tested [45]. A patient with clinical syndrome associated with MERS, for which he may be suspected of MERS respiratory disease [46]. 
However, such must also be supported with a duration lasting for more than 2 weeks from which the suspicion was e first noted [36, 37].

The Virus Associated With MERS Infection: Middle East respiratory syndrome corona virus otherwise termed as the (MERS- CoV) falls under the class of infection termed as beta corona virus. Such is a very unique virus since it does fall among human causing virus yet it causes infection to human beings. Another possible confusing fact is that Middle East respiratory syndrome virus has much more relationship to corona viruses causing organism in bats. Never the less, it is characterized by a Dipeptidyl peptidase (DPP4) that is transmitted through human cells into the receptor. The potentiality of the virus to transmit itself through the conciliated bronchial epithelial cells makes it more adaptable for infection in human [69]. As a result, the virus is able to harbor itself within the protein consequent and obtain a cyst making it very difficult to die.The susceptibility of MERS infection is found in a number of human cells located various body organs such as the colon, kidney and liver among others [67]. The rate at which the virus multiplies in such organs is promoted by the conducive-environment exhibited by cells in those organs. Results have also confirmed that the tropic cycle of the virus is much broader than any other human corona virus that increases its level of growth [61]. Possible enough; the virus is adaptable to human bronchial cells that also promote the rate of infection. Ultimately, it has also been confirmed that the virus also attacks other animals such as monkey, rabbit and donkey among others apart from human [64]. Worst of all, corona virus can transforms into greater species at the vivo infection stage [62].

MERS Topological Distribution: As from early 2012, the infection of East respiratory syndrome virus had been confirmed in the Middle Eastern region of the world by the world health organization [63]. Moreover, other possible reports also confirmed a similar infection most especially among the countries falling within the Arabian Peninsula. While MERS infection has been felt in different countries within the same region, high rate of prevalence has been felt within Saudi Arabia-(figure 1). However, similar cases, but to a lower capacity have been felt in other countries such as Africa Europe or Asia [60]. However, cases report outside the prevalent regions are said to be from patients who may have had a previous contact with an infected person or maybe after having traveled from such infected regions [70]. Due to consistent reports of the same infection within Saudi Arabia till late 2014, MERS was classified as one of the most dangerous diseases in peninsular region [59]. However, the non-explicative nature of the virus has made it more neutral affecting other countries outside the region. The teropoligical nature of this disease has made it to be classified as not only infectious, but also simultaneous in regions that are perceived predominant [71].

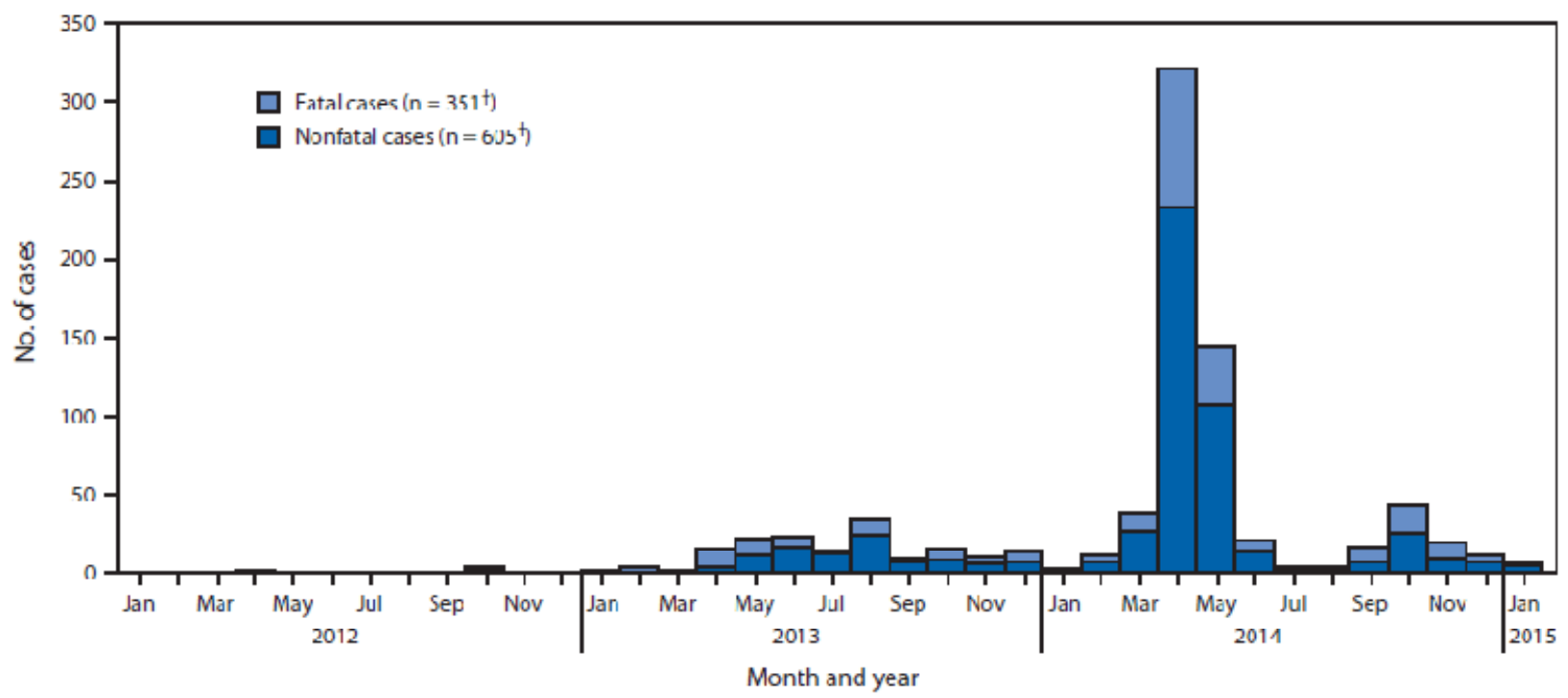

Figure 1: Cases of Middle East respiratory syndrome within Saudi Arabia between 2012-2015

Epidemiological Transmission Mode: A good number of MRS cases that have since been experienced in both eastern and southern part of Saudi Arabia and its environment have been acquired from unknown source [73]. However, the WHO confirmed that the suspicion from a zoonotic transmission in the peninsular region and Yemen. Bats and viruses: 
From pathogen discovery to host genomics (P-42) reports that a possible transmission mode of the virus is unclear, but $80 \%$ of infections confirmed are through Carmel. For instance, in a laboratory test of 12 infected patients, it found that the victims may have had a previous contact with the Carmel [74]. Therefore; Carmel is a fumitory evidence or asymptomatic mode for MERS transmission. Moreover, 54\% of patients who had such relationships remained positive for the viral infection especially their upper respiratory track [44]. Additionally, a case of infection that was found to have been reported in Jeddah in June 2013 showed that the asymptomatic patient was a Carmel farmer in Riyadh [45]. However, the transmission level was low since the person in question experienced a lower level of infection since he had very minimal interaction to the public.

Table 1: Confirmed MERS cases in Oman by age and sex, March 2012-25 September 2012

\begin{tabular}{|l|r|r|r|r|r|}
\hline & \multicolumn{3}{|c|}{ Male } & \multicolumn{3}{|c|}{ Female } & \\
\hline Age (years) & Dead & Total & dead & Total & Total number of cases \\
\hline 10 to 19 & 0 & 3 & 1 & 5 & 8 \\
\hline 20 to 29 & 0 & 4 & 0 & 8 & 12 \\
\hline 30 to 39 & 0 & 2 & 4 & 2 & 4 \\
\hline 40 to 49 & 0 & 7 & 5 & 6 & 13 \\
\hline 50 to 59 & 2 & 9 & 3 & 2 & 11 \\
\hline 60 to 69 & 2 & 11 & 7 & 0 & 11 \\
\hline 70 to 79 & 5 & 8 & 14 & 4 & 12 \\
\hline 80 to 89 & 0 & 5 & 12 & 3 & 8 \\
\hline 90 to 99 & 12 & 2 & 5 & 1 & 3 \\
\hline Case fatality & $24 \%$ & & $54 \%$ & & \\
\hline
\end{tabular}

Bats: Another possible mode MERS virus transmission is through bats. Most laboratory researches have confirmed bat as a possible mode of transmission continents such as Africa, Europe and the Middle East. In early October 2012, samples collected by the ministry of health within Saudi Arabia confirmed possible infection of MERS virus [46]. Besides, the CDC working in conjunction with the University of Colombia also confirmed the same out of an investigation where patients from a case family were interviewed in Bishah [47, 48]. Moreover, another research sample conducted in Lebanon tested positive results of corona virus RNA virus with others not showing exact, but possible traits of virus.

In Oman, fecal and rectal swab samples gathered from the government healthcare training center for infectious diseases tested positive of corona virus infection [49]. Nevertheless, the level of fecal pellets though not much, but has since gained gradual development in areas where bats commonly share dwelling units with human being [50]. Critical information towards accurate evaluation of the disease transmission through bats has confirmed a direct and sequential epidemic potentiality amongst bats. In essence, a man-aged 46 years who was admitted at a hospital in Jeddah showed that the man had a habitual relationship with bats that were associated with nasal discharge right ahead before the patient's admission [51].

Camels: From most of the statistics collected, it is noted with deep concerns that that camels acts as horde for MERS-CoV infection. Some of the strongest evidence has been found within Saudi Arabia. For instance, a man who had been previously admitted under intensive care unit was found to have had a previous physical contact with a Carmel. Therefore, it can be confirmed that there is a genome sequence demonstrated by the virus both in men and animals.

\section{Infection Prevention and Control in Health Care: As} per the recommendations of the world health organizations, there is need for countries that are prone to infection to apply preventive measures to tame the prevalence of infection [58]. As part of a major concern, guidelines for possible prevention have been acknowledge through screening of the infected patients and probable measure be taken [52]. Up to date, medical researchers have not developed any specific clinical preventive method for MERS infection. None 
the less, possible control mechanism such as travel advisory has been created to curb a continued escalation of the virus menace [59]. Besides, the world health organization recommended that patients with acute respiratory syndrome be placed on convalescent plasma or be given antibody additives to protect people from further respiratory infection. In early 2014, a forum was convened by the international network of clinical experts who recommended that more vaccines be developed e to mitigate a continued menace [53]. As a result international standard principles were developed with objectives much similar to the ones that were used to curb the menace of avian flu [54].

Screening is recommended as the first method targeting to eliminate infected patients from the rest [55]. Therefore, amplification should be provided supported with a deep nucleic extraction to confirm a real case of infection [56]. Such a procedure have since been used in Dubai and Saudi Arabia where over $50 \%$ of the nucleic generated components of the suspected victims have turned positive of infection [57]. From a nucleic acid generated from over 200 samples mixed with aspirate will definitely give a confirmation of a disease infection [7].

\section{Conclusion}

Middle East respiratory syndrome corona virus (MERS$\mathrm{CoV}$ ) causing severe respiratory distress emerged in 2012 in Saudi Arabia. There is currently no treatment recommended for corona virus infections except for supportive care as needed. There is no licensed vaccine for MERS-CoV.

\section{Funding: Nil, Conflict of interest: None. Permission of IRB: Yes}

\section{References}

1. Reusken CB, Farag EA, Jonges M, Godeke GJ, ElSayed AM, Pas SD, Raj VS, Mohran KA, Moussa HA, Ghobashy H, Alhajri F, Ibrahim AK, Bosch BJ, Pasha SK, Al-Romaihi HE, Al-Thani M, Al-Marri SA, AlHajri MM, Haagmans BL, Koopmans MP. Middle East respiratory syndrome corona virus (MERS$\mathrm{CoV})$ RNA and neutralising antibodies in milk collected according to local customs from dromedary camels, Qatar, April 2014. Euro Surveill. 2014 Jun 12; 19(23). pii: 20829.

2. Lipkin WI. Middle East Respiratory Syndrome Corona virus Recombination and the Evolution of
Science and Public Health in China. MBio. 2015 Sep 8; 6(5):e01381-15. doi: 10.1128/mBio.01381-15.

3. Shahkarami M, Yen C, Glaser C, Xia D, Watt J, Wadford DA. Laboratory Testing for Middle East Respiratory Syndrome Corona virus, California, USA, 2013-2014. Emerg Infect Dis. 2015 Sep; 21(9):1664-6. doi: 10.3201/eid2109.150476.

4. Preston R. The hot zone. New York: Random House; 1994.

5. Bennett J, Dolin R, Blaser M, Mandell G, Douglas R. Mandell, Douglas, and Bennett's principles and practice of infectious diseases.

6. Berger, S., \& Gideon Informatics, Inc. Infectious diseases of the United Arab Emirates. Los Angeles, California : GIDEON Informatics, Inc. 2015.

7. Brunette G, Kozarsky P, Cohen N. CDC health information for international travel 2016.

8. Deutsche GesellschaftfürKristallog-raphie. 22. Jahrestagung .bis 20. März 2014, Berlin: Abstracts. 2014.

9. Guery B, Poissy J, el Mansouf L, Séjourné C, Ettahar $\mathrm{N}$, Lemaire $\mathrm{X}$ et al. Clinical features and viral diagnosis of two cases of infection with Middle East Respiratory Syndrome corona virus: a report of nosocomial transmission. The Lancet. 2013; 381(9885):2265-2272.

10. Memish ZA, Zumla AI, Al-Hakeem RF, AlRabeeah AA, Stephens GM. Family cluster of Middle East respiratory syndrome corona virus infections. N Engl J Med. 2013 Jun 27; 368(26):2487-94. doi: 10.1056/NEJMoa1303729. Epub 2013 May 29.

11. van Doremalen N, Bushmaker T, Munster VJ. Stability of Middle East respiratory syndrome coronavirus (MERS-CoV) under different environmental conditions. Euro Surveill. 2013 Sep 19; 18(38). pii: 20590 .

12. Al-Gethamy M, Corman VM, Hussain $\mathrm{R}, \mathrm{Al}$ Tawfiq JA, Drosten C, Memish ZA. A case of longterm excretion and subclinical infection with Middle East respiratory syndrome corona virus in a healthcare worker. Clin Infect Dis. 2015 Mar 15; 60(6):973-4. doi: 10.1093/cid/ciu1135. Epub 2014 Dec 16. 
13. Cotten M, Watson SJ, Kellam P, Al-Rabeeah AA, Makhdoom HQ, Assiri A, Al-Tawfiq JA, Alhakeem RF, Madani H, AlRabiah FA, Al Hajjar S, Al-nassir WN, Albarrak A, Flemban H, Balkhy $\mathrm{HH}$, Alsubaie S, Palser AL, Gall A, Bashford-Rogers R, Rambaut A, Zumla AI, Memish ZA. Transmission and evolution of the Middle East respiratory syndrome corona virus in Saudi Arabia: a descriptive genomic study. Lancet. 2013 Dec 14;382(9909):1993-2002. doi: 10.1016/S0140-6736(13)61887-5. Epub 2013 Sep 20.

14. Mailles A, Blanckaert K, Chaud P, van der Werf S, Lina B, Caro V, Campese C, Guéry B, Prouvost H, Lemaire X, Paty MC, Haeghebaert S, Antoine D, Ettahar N,Noel H, Behillil S, Hendricx S, Manuguerra JC, Enouf V, La Ruche G, Semaille C, Coignard B, Lévy-Bruhl D, Weber F, Saura C, Che D; investigation team. First cases of Middle East Respiratory Syndrome Corona virus (MERS-CoV) infections in France, investigations and implications for the prevention of human-to-human transmission, France, May 2013. Euro Surveill. 2013 Jun 13;18(24). pii: 20502.

15. Penttinen PM, Kaasik-Aaslav K, Friaux A, Donachie A, Sudre B, Amato-Gauci AJ, Memish ZA, Coulombier D. Penttinen $\mathrm{PM}^{1}$, Kaasik-Aaslav $\mathrm{K}$, Friaux A, Donachie A, Sudre B, Amato-Gauci AJ, Memish ZA, Coulombier D. Euro Surveill. 2013 Sep 26; 18(39). pii: 20596.

16. Ithete NL, Stoffberg S, Corman VM, Cottontail VM, Richards LR, Schoeman MC, Drosten C, Drexler JF, Preiser W. Close relative of human Middle East respiratory syndrome corona virus in bat, South Africa. Emerg Infect Dis. 2013 Oct; 19(10):1697-9. doi: 10.3201/eid1910.130946.

17.Cauchemez S, Van Kerkhove MD, Riley S, Donnelly CA, Fraser C, Ferguson NM. Euro Surveill. 2013 Jun 13; 18(24). pii: 20503.

18. Hall RA, Tan SE, Selisko B, Slade R, HobsonPeters J, Canard B, Hughes M, Leung JY, BalmoriMelian E, Hall-Mendelin S, Pham KB, Clark DC, Prow NA,Khromykh AA. Monoclonal antibodies to the West Nile virus NS5 protein map to linear and conformational epitopes in the methyltransferase and polymerase domains. J Gen Virol. 2009 Dec; 90(Pt 12):2912-22. doi: 10.1099/vir.0.013805-0. Epub 2009 Aug 26.
19. Maumus F, Fiston-Lavier A, Quesneville H. Impact of transposable elements on insect genomes and biology. Current Opinion in Insect Science. 2015; 7:3036.

20. Memish ZA, Cotten M, Meyer B, Watson SJ, Alsahafi AJ, Al Rabeeah AA, Corman VM, Sieberg A, Makhdoom HQ, Assiri A, Al Masri M, Aldabbagh S, Bosch BJ,Beer M, Müller MA, Kellam P, Drosten C. Human infection with MERS corona virus after exposure to infected camels, Saudi Arabia, 2013. Emerg Infect Dis. 2014 Jun; 20(6):1012-5. doi: 10.3201/eid2006.140402.

21. Adney DR, van Doremalen N, Brown VR, Bushmaker T, Scott D, de Wit E, Bowen RA, Munster VJ. Replication and shedding of MERS$\mathrm{CoV}$ in upper respiratory tract of inoculated dromedary camels. Emerg Infect Dis. 2014 Dec; 20(12):19992005. doi: 10.3201/eid2012.141280.

22. Rasmussen A. L., Falzarano D., de Wit E., Feldmann, F., Okumura, A., Scott, D. P., \&Katze, M. G. 206: Transcriptional signatures of pathogenesis and successful type I interferon and ribavirin therapy in a rhesus macaque model of MERS-CoV infection. Cytokine, 2014; 63(3), 291-292.

23. Wang L, Cowled C. Bats and viruses: From pathogen discovery to host genomics. Hoboken, New Jersey : Wiley-Blackwell. 2015.

24. Berger S. SARS and MERS: Global status. 2015; Los Angeles, California : Gideon.

25. Gostin L. Global health law.. Cambridge, Massachusetts : Harvard University Press. 2014.

26. 27Kaslow R, Stanberry L, LeDuc J. Viral infections of humans.: Epidemiology and control. 2014.

27. Fraire A. Viruses and the lung: Infections and noninfectious viral-linked lung disorders. 2014.

28. Mestecky J. Mucosal immunology. Amsterdam: Elsevier Academic Press; 2005.

29. Guery B, Poissy J, el Mansouf L, Séjourné C, Ettahar N, Lemaire X, Vuotto F, Goffard A, Behillil S, Enouf V, Caro V, Mailles A, Che D, Manuguerra JC, Mathieu D,Fontanet A, van der Werf S; MERSCoV study group. Clinical features and viral diagnosis of two cases of infection with Middle East Respiratory 
Syndrome corona virus: a report of nosocomial transmission. Lancet. 2013 Jun 29; 381(9885):2265-72. doi: 10.1016/S0140-6736(13)60982-4. Epub 2013 May 30 .

30. Meyer B, Müller MA, Corman VM, Reusken CB, Ritz D, Godeke GJ, Lattwein E, Kallies S, Siemens A, van Beek J, Drexler JF, Muth D, Bosch BJ, Wernery U,Koopmans MP, Wernery R, Drosten C. Antibodies against MERS corona irus in dromedary camels, United Arab Emirates, 2003 and 2013. Emerg Infect Dis. 2014 Apr; 20(4):552-9. doi: 10.3201/eid2004.131746.

31. Raj VS, Osterhaus $\mathrm{AD}^{1}$, Fouchier RA, Haagmans BL. MERS: emergence of a novel human corona virus. Curr Opin Virol. 2014 Apr; 5:58-62. doi: 10.1016/j.coviro.2014.01.010. Epub 2014 Feb 28.

32. Coleman CM, Matthews KL, Goicochea L, Frieman MB. Wild-type and innate immune-deficient mice are not susceptible to the Middle East respiratory syndrome corona virus. J Gen Virol. 2014 Feb; 95(Pt 2):408-12. doi: 10.1099/vir.0.060640-0. Epub 2013 Nov 6.

33. Chan S. The unfolded protein response in virus infections. Front Microbiol. 2014;5.

34. CaronR. Preparing the public health workforce: Educational path-ways for the field and the classroom. 2014.

35. Singer M. The anthropology of infectious disease. Walnut Creek, California : Left Coast Press, Inc. 2015.

36. John G, In Kozarsky P, In Cohen N, National Center for Emerging and Zoonotic Infectious Diseases (U.S.)., \& Oxford University Press,. (2016). CDC health information for international travel. 2015.

37. Grad Y, Newman R, Zody M, Yang X, Murphy R, $\mathrm{Qu} \mathrm{J}$ et al. Within-Host Whole-Genome Deep Sequencing and Diversity Analysis of Human Respiratory Syncytial Virus Infection Reveals Dynamics of Genomic Diversity in the Absence and Presence of Immune Pressure. Journal of Virology. 2014; 88(13):7286-7293.

38. Gossner C, Danielson N, Gervelmeyer A, Berthe F, Faye B, KaasikAaslav K et al. Human-Dromedary Camel Interactions and the Risk of Acquiring Zoonotic
Middle East Respiratory Syndrome Corona virus Infection. Zoonoses Public Health. 2014; 63(1):1-9.

39. Schneider E, Chommanard C, Rudd J, Whitaker B, Lowe L, Gerber SI. Evaluation of Patients under Investigation for MERS-CoV Infection, United States, January 2013-October 2014. Emerg Infect Dis. 2015 Jul; 21(7):1220-3. doi: 10.3201/eid2107.141888.

40. Lennette E, Halonen P, Murphy F, Balows A, \& Hausler W. Laboratory Diagnosis of Infectious Diseases Principles and Practice: VOLUME II Viral, Rickettsial, and Chlamydial Diseases. New York, NY: Springer New York. 1988.

41. Pevsner J. Bioinformatics and Functional Genomics. Hoboken: John Wiley \& Sons. 2005.

42. Liess B, Moennig V, Pohlenz J, \& Trautwein G. Ruminant Pestivirus Infections: Virology, Pathogenesis, and Perspectives of Prophylaxis. Vienna: Springer Vienna. 2009.

43. Kaslow R, Stanberry L, \& LeDuc J. Viral infections of humans: Epidemiology and control. New York : Springer. 2014.

44. Stoller J. Murray \& Nadel's Textbook of Respiratory Medicine, 6th Edition. Annals ATS. 2015; 12(8):1257-1258.

45. Wang L, Cowled C. Bats and viruses. Bats and viruses: From pathogen discovery to host genomics. Hoboken, New Jersey : Wiley-Blackwell . 2015.

46. World Health Organization. Infection prevention and control during health care for probable or confirmed cases of Middle East respiratory syndrome corona virus (MERS-CoV) infection Interim guidance Updated. 2015; 4 June 2015.

47. Schneider E, Chommanard C, Rudd J, Whitaker B, Lowe L, Gerber SI. Evaluation of Patients under Investigation for MERS-CoV Infection, United States, January 2013-October 2014. Emerg Infect Dis. 2015 Jul; 21(7):1220-3. doi: 10.3201/eid2107.141888.

48. Zumla A, Hui DS. Infection control and MERS$\mathrm{CoV}$ in health-care workers. Lancet. 2014 May 31; 383(9932):1869-71. doi: 10.1016/S01406736(14)60852-7. Epub 2014 May 20. 
49. Caron R. Preparing the public health workforce: Educational path-ways for the field and the classroom. 2014.

50. Kasper D, Harrison T. Harrison's principles of internal medicine. New York: McGraw-Hill, Medical Pub. Division; 2005.

51. Weston D. Fundamentals of infection prevention and control. Chichester, West Sussex, U.K.: WileyBlackwell; 2013.

52. Stapleton FB. Hematuria associated with hypercalciuria and hyperuricosuria: a practical approach. Pediatr Nephrol. 1994 Dec; 8(6):756-61.

53. Madani TA, Althaqafi AO, Alraddadi BM. Infection prevention and control guidelines for patients with Middle East Respiratory Syndrome Corona virus (MERS-CoV) infection. Saudi Med J. 2014 Aug; 35(8):897-913.

54. Hall AJ, Tokars JI, Badreddine SA, Saad ZB, Furukawa E, Al Masri M, Haynes LM, Gerber SI, Kuhar DT, Miao C, Trivedi SU, Pallansch MA, Hajjeh R, Memish ZA. Health care worker contact with MERS patient, Saudi Arabia. Emerg Infect Dis. 2014 Dec; 20(12):2148-51. doi: 10.3201/eid2012.141211.

55. Wittekamp BH, Wise MP, Brun-Buisson C, Bonten MJ. Regulatory obstacles affecting ecological studies in the ICU. Lancet Infect Dis. 2014 Oct; 14(10):913-5. doi: 10.1016/S1473-3099(14)70894-1.

56. Tulchinsky, T. H., \& Varavikova. The new public health. 2014.

57. Broaddus, V. C., Mason, R. C., Ernst, J. D., King, T. E. J., Lazarus, S. C., Murray, J. F., Nadel, J. A., ... Gotway, M. Murray \& Nadel's Text-book of Respiratory Medicine. Lon-don: Elsevier Health Sciences. 2015.

58. Glanz K, Rimer B, Lewis F. Health behavior and health education. San Francisco: Jossey-Bass; 2002.

59. Pavli A, Tsiodras S, Maltezou H. Middle East respiratory syndrome coronavirus (MERS-CoV): Prevention in travelers. Travel Medicine and Infectious Disease. 2014; 12(6):602-608.
60. Pavli A, Tsiodras S, Maltezou HC. Middle East respiratory syndrome corona virus (MERS-CoV): prevention in travelers. Travel Med Infect Dis. 2014 Nov-Dec; $\quad 12(6 \quad$ Pt $\quad$ A):602-8. doi: 10.1016/j.tmaid.2014.10.006. Epub 2014 Oct 19.

61. Gautret P, Charrel R, Benkouiten S, Belhouchat K, Nougairede A, Drali T, Salez N, Memish ZA, Al Masri M, Lagier JC, Million M, Raoult D, Brouqui P, Parola P. Lack of MERS corona virus but prevalence of influenza virus in French pilgrims after 2013 Hajj. Emerg Infect Dis. 2014 Apr;20(4):728-30. doi: 10.3201/eid2004.131708.

62. Gibson GJ, Loddenkemper R, Lundbäck B, Sibille Y. Respiratory health and disease in Europe: the new European Lung White Book. Eur Respir J. 2013 Sep;42(3):559-63. doi: 10.1183/09031936.00105513.

63. Marriane, T. H., \& Wiley, E. The new public health. Amsterdam: Academic Press. 2014.

64. Mailles A, Blanckaert K, Chaud P, van der Werf S, Lina B, Caro V, Campese C, Guéry B, Prouvost H, Lemaire X, Paty MC, Haeghebaert S, Antoine D, Ettahar N,Noel H, Behillil S, Hendricx S, Manuguerra JC, Enouf V, La Ruche G, Semaille C, Coignard B, Lévy-Bruhl D, Weber F, Saura C, Che D; investigation team. First cases of Middle East Respiratory Syndrome Corona virus (MERS-CoV) infections in France, investigations and implications for the prevention of human-to-human transmission, France, May 2013. Euro Surveill. 2013 Jun 13; 18(24). pii: 20502.

65. Chiu S, Hung Chan K, Wing Chu K, Kwan S, Guan Y, Man Poon L et al. Human Corona virus NL63 Infection and Other Corona virus Infections in Children Hospitalized with Acute Respiratory Disease in Hong Kong, China. Clinical Infectious Diseases. 2005; 40(12):1721-1729.

66. Mandell L, Bartlett J, Dowell S, File T, Musher D, Whitney C. Update of Practice Guidelines for the Management of Community-Acquired Pneumonia in Immunocompetent Adults. Clinical Infectious Diseases. 2003; 37(11):1405-1433.

67. Vabret A, Mourez T, Gouarin S, Petitjean J, Freymuth F. An outbreak of corona virus OC43 respiratory infection in Normandy, France. Clin Infect Dis. 2003 Apr 15; 36(8):985-9. Epub 2003 Apr 4. 
68. Wong SS The management of corona virus infections with particular reference to SARS. J Antimicrob Chemother. 2008 Sep; 62(3):437-41. doi: 10.1093/jac/dkn243. Epub 2008 Jun 18.

69. Engelkirk P, Duben-Engelkirk J, Burton G. Burton's microbiology for the health sciences. Philadelphia: Wolters Kluwer Health/Lippincott Williams \& Wilkins; 2011.
70. San Die-go: Academic Press. Viral ecology. 2000.

71. Spinage C. African ecology. Berlin: Springer; 2012.

72. Yu IT, Li Y, Wong TW, Tam W, Chan AT, Lee JH, Leung DY,Ho T. Evidence of airborne transmission of the severe acute respiratory syndrome virus. N Engl J Med. 2004 Apr 22; 350(17):1731-9.

\section{How to cite this article?}

Al-Ghamdi S. Update on Middle East respiratory syndrome corona virus epidemiology, diagnosis and management. Int J Med Res Rev 2016;4(1): 104-112. doi: 10.17511/ijmrr.2016.i01.016. 